\title{
The Impact of Audit Committee Characteristics on Earnings Management: A Canadian Case Study
}

\author{
Lynda Ioualalen \\ Department of Accounting, University of Quebec in Montreal \\ PO Box 8888, Montréal (Québec) H3C 3P8 \\ Tel: 1-514-987-3000Ｅ-mail: ioualalen.lynda@courrier.uqam.ca
}

Hanen Khemakhem

Department of Accounting, University of Quebec in Montreal

PO Box 8888, Montréal (Québec) H3C 3P8

Tel: 1-514-987-3000 E-mail: khemakhem.hanen@uqam.ca

\begin{abstract}
Richard Fontaine (Corresponding author)
Department of Accounting, University of Quebec in Montreal

PO Box 8888, Montréal (Québec) H3C 3P8
\end{abstract}

Tel: 1-514-987-3000Ｅ-mail: fontaine.richard@uqam.ca

Received: May 29, 2015 Accepted: June 16, 2015 Published: June 26, 2015

doi:10.5296/csbm.v2i1.7901 URL: http://dx.doi.org/10.5296/csbm.v2i1.7901

\begin{abstract}
The objective of this study was to analyze the impact of three Audit Committee (AC) characteristics, financial expertise, diversity and activism on aggressive earnings management. We hypothesized that these AC characteristics are negatively related to aggressive earnings management. To test or hypothesis, we conducted an empirical test with a sample of 10 Canadian corporations listed on the Toronto stock exchange: 5 companies that were accused of aggressive earnings management and 5 other corporations used as a control group. We analyzed the 5-year period prior to the accusation (1999-2003). We measured earnings management by the level of discretionary accruals (using the modified Jones model (1995). Our results show that activism and the financial expertise of AC members are
\end{abstract}




\section{Macrothink}

Case Studies in Business and Management

ISSN 2333-3324

2015, Vol. 2, No. 1

negatively related to aggressive earnings management; however, we did not find a significant relationship between diversity and aggressive earnings management. These results contribute to help governance oversight organizations identify AC characteristics that have the most influence on the detection of aggressive earnings management, which could help agencies develop and enforce methods to detect and reduce aggressive earnings management practices.

Keywords: Corporate governance, audit committee, aggressive earnings management, discretionary accruals 


\section{Introduction}

In recent financial scandals in corporations such as Enron, Xerox and Waste Management, publically disclosed accounting information was manipulated. Different mechanisms exist to control against accounting information manipulation (also know as aggressive earnings management). The Board of Directors and it's Audit Committee (AC) play are examples of such mechanisms of control (Fama et Jensen, 1983; Charreaux, 1993).

In fact, the $\mathrm{AC}$ is considered an internal control mechanism that plays an important role to verify the reliability of the production process of financial information (Naciri, 2011). The $\mathrm{AC}$ also plays a central role in the reduction of the discretional power of management and in assuring the confidence of external investors.

After a revue of literature on the causes of aggressive earnings management we identified certain AC characteristics such as activism, financial expertise and diversity that could improve the quality of earnings management (Bedard et al., 2001; Xie et al., 2003; Lin et Hwang, 2009; Thomas, 2011).

This past research only analyzed the impact of either $1 \mathrm{AC}$ characteristic on earnings management (Lan et al., 2011) or the impact of different AC characteristics on earnings management such as activism and independence (Xie et al., 2003), meeting frequency and financial expertise (Lin et Hwang, 2009). No study investigated the combined effect of 3 important AC characteristics (financial expertise, activism and diversity) on aggressive earnings management. Grouping these $3 \mathrm{AC}$ characteristics together is important due to recent changes in Canadian AC regulations.

This Canadian regulation change has modified the composition and the role of the AC; therefore, it is important to test the impact of these characteristics on earnings management. The contribution of this research lies in the absence of past studies that tested the impact of these AC characteristics in a Canadian context. Therefore our research question is, what is the impact of financial expertise, activism (frequency of $\mathrm{AC}$ meetings) and diversity on aggressive earnings management practices in Canadian corporations?

To answer this research question we used a sample of 5 Canadian companies that were accused of aggressive earnings manipulation by the Quebec Securities Exchange (AMF). More precisely, we analyzed the impact of all three characteristics (financial expertise, activism and diversity) on the practices of aggressive earnings manipulation accounting conducted by the companies in our sample. These manipulations were denounced by the AMF and were considered as aggressive earnings management, resulting in a required earnings restatement.

The results of our study suggest that financial expertise and activism have a negative impact on aggressive earnings management practices. However, regarding diversity, we did not find any significant impact on earnings management. This article is organized by first presenting a revue of the pertinent literature, including our conceptual framework and hypotheses. We then present the methodology along with the results and a final discussion. 


\section{Revue of Literature}

In the following Literature Review we define the terms in our conceptual framework and justifies the study's hypotheses.

\subsection{Earnings Management}

Pochet (1998) defines aggressive earnings management as a deliberate intervention in the process of preparing accounting information. In fact, accounting regulations allow for a certain number of accounting choices, resulting in room for interpretation. A legal interpretation adhering to accounting regulations does not guarantee that financial statements provide a faithful representation of the financial situation of an organization (Stolowy et Broton, 2003).

According to Stolowy (1999), earnings management is the sum of procedures with the objective to modify the level of net income. However, earnings management is not limited to net income (Barnea et al., 1975; Ronen et Sadan, 1975). It can also affect the balance sheet and cash flow (Black et al., 1998). The problem with the various accounting choices is that accounting standards have not set clear and precise limits which would be considered not permitted (illegal), which allows management a large margin of leeway for earnings manipulation.

In addition, management communicates to financial statement users private information and take advantage of their decisional leeway to manipulate information in order to present financial information that does not fully represent the real financial position of the organization (Pochet, 1998).

\subsection{Reasons for Earnings Management}

Many reasons could motivate management to manipulate accounting information such as maximizing the wealth of management when bonuses are calculated based on accounting profits (Magnan, 1996). Also, there is the transfer of wealth from certain stakeholders towards shareholders, especially for companies with controlling shareholders (Breton et Schatt, 2003). Managers manipulate to minimize financing costs: public offering, mergers and acquisitions and leveraged buy outs (Magnan et Cormier, 1997; Erickson et Wang, 1999). Managers also manipulate to avoid violating debt restrictions, which could be costly (Defond et Jiambelvo, 1994).

Therefore, we confirm that many different reasons could motivate manages to manipulate earnings which differ from one company to another based on different objectives. However, the audit committee, given its role in the corporation, examines the majority of the choices of accounting methods and they control the integrity of the financial information and financial statements of the corporation (Pochet, 1998). We therefore suppose that the AC could detect the existence of aggressive earnings management practices in organizations taken into account in their analysis all the elements that could motivate managers to present a financial situation different than the actual financial situation. 


\subsection{The Role of the AC on Earnings Management Practices}

The AC is a committee constituted by the Board of Directors which is composed of administrators who are responsible for overseeing the accounting processes et the communication of financial information and the financial statement audit by external auditors (Québec, 2005).

In addition, modifications to Canadian regulations (Regulation 52-110) obliges the AC to be composed of 3 independent members of which 1 member needs to be a financial expert that needs the capabilities to read and understand financial statements that could require complex accounting questions. These measures were intended to reinforce the power of control of the $\mathrm{AC}$ regarding financial statements as well as the supervision of accounting policies.

Various studies investigated the relationship between the AC characteristics and aggressive earnings management (Bedard et al., 2001; CPA Canada, 2012a, IAS 19.75; Lin et Hwang, 2009; Thomas, 2011). In addition to AC characteristics such as independence, financial expertise, and activism, prior literature suggests that personal attributes such as gender, age, industry knowledge. Moreover origin and values could affect aggressive earnings management decisions by managers (LAN et al., 2011; Thomas, 2011). Since there exists very little research in this area, this study contributes to this field of knowledge, in a Canadian context.

\subsection{The Impact of AC Activism on Aggressive Earnings Management Practices}

$\mathrm{AC}$ activism constitutes of the total number of AC meetings, ordinary and (Xie et al., 2003; Lin et Hwang, 2009; Thomas, 2011; Bedard et al., 2004). Bédard et al. (2001) examined the relationship between activism and earnings management measured by the level of discretionary accruals. They used 2 groups of American companies: one group characterized by a high level of discretionary accruals and another group by a low level of discretionary accruals. They found that an AC that have a clear mandate to oversee financial statements, made up of only independent administrators that meet 2 times per year conduct less earnings management.

However, Thomas (2011) examined the relationship between AC characteristics and earnings management with a sample of French companies during the period of 2007-2009. The results showed a negative relationship between the number of administrators and the frequency of meetings and financial expertise of the AC in French companies.

Xie et al. (2003) corroborate these findings with a sample of S\&P500 companies in 1992, 1994 and 1996 who found that the proportion of independence administrators of the AC does not affect discretionary accruals. Variables measuring competency (the proportion of directors having executive responsibilities in other firms) as well as the number of AC meetings are associated with less accruals; but the researchers did not simultaneously take into account these characteristics. However, Bedard et al. (2004) did not find any significant association between the frequency of AC meetings and earnings management. These results of Thomas (2011), Xie et al. (2003) and Bédard et al. (2001), show that AC activism is negatively associated with earnings management practices; therefore, our first hypothesis is 
the following:

\section{H1: AC activism is negatively related to aggressive earnings management.}

\subsection{The Impact of Financial Expertise on Aggressive Earnings Management Practices}

According to the National Policy 52-110 one of the AC members must have financial competency assuring they can read and understand the corporations' financial statement and demonstrate proof of critical thinking. This variable was used by several researchers (Bédard et al., 2001; Lin et Hawang, 2009; Thomas, 2011; et Ghosh et al., 2011).

Lin et Hwang (2009) examined the role of a group of AC and Board characteristics on earnings management in American companies. They found a negative relationship between earnings manipulation and $\mathrm{AC}$ characteristics such as independence, financial expertise, size, frequency of meetings and shareholder. Similarly, Bédard et al. (2001) also found a negative relationship between the presence of financial experts in the $\mathrm{AC}$ and earnings management.

The results of Thomas (2011), corroborate the preceding results showing a negative relationship between financial expertise and earnings management for French companies. Contrarily, Ghosh et al. (2010) analyzed the relationship between the AC Characteristics such as the composition, activism, financial expertise, share structure and tenure with earnings management before and after the Sarbanes Oxley Act with a sample of American companies. Their results did not show a relationship between composition, financial expertise and shareholder structure in the AC with earnings management practices.

In addition, the results of the study by Lin et Hawang (2009) and Thomas (2011) show that financial expertise of the members of an $\mathrm{AC}$ have a negative relationship with earnings management. Therefore our second hypothesis is the following:

H2: Financial expertise of the members of the AC is negatively related to aggressive earnings management.

These prior studies (Bédard et al., 2001; Lin et Hawang, 2009; Thomas, 2011; et Ghosh et al., 2011), group AC characteristics and analyze their impact on earnings management with the exception of diversity. Diversity is the subject of recent recherché especially with the adoption of the law on diversity in 2006 in Canada. Québec adopted a law in 2006 that adopted a law that by the $14^{\text {th }}$ of December $2011,50 \%$ of the seats at the Board and their committees need to be held by women.

\subsection{The Impact of Diversity of the AC on Earnings Management}

The presence of women on ACs has been the subject of both theoretical and empirical studies such as Gul et al. (2007), et Lan et al. (2011). The question remains if the presence of women on ACs could have an impact on earnings management. The answer to this question is mitigated between proponents and opponents of gender diversity in ACs. In fact, Gul et al. (2007) examined the impact of gender diversity in ACs on earnings management. They found that earnings management is weak for companies where the $\mathrm{AC}$ has women. Their results were justified by the fact that women possess a greater capacity to communicate compared to 
males and they treat questions strategically, which results in less earnings management practices.

However, Lan et al. (2011) examined the impact of the gender of AC members on earnongs management practices using a sample of 525 americin companies for the period covering 2003-2005. They found no association between the proportion of women in ACs and earnings management practices. Similarly the results of Gul et al. (2007) showed that diversity of the members of ACs that measure the presence of women on ACs is negatively associated with earnings management; therefore our third hypothesis is the following:

\section{H3: The diversity in ACs is negatively related to earnings management.}

Several researchers showed a negative relationship between earnings management measured by discretionary accruals and certain AC characteristics (Bedard et al., 2001; Xie et al., 2003; Lin et Hwang, 2009; Thomas, 2011). However, (Bedard et al., 2004; Ghosh et al., 2011; Lan et al., 2011) were unable to show any association between AC characteristics and earnings management.

In general, we can conclude that there is a conflict in the literature regarding the relationship between the $\mathrm{AC}$ and the detection of aggressive earnings management practices, difficult to see any clear consensus. These results motivate the important reflection on earnings management in Canada. This is especially important after the instauration of the regulation 52-110 regarding ACs by the Québec Exchange Commission (AMF), in response to financial scandals. Given the absence of past research analyzing the impact of diversity, financial expertise and activism on aggressive earnings management in Canada, this study contributes to this knowledge.

The majority of these studies are based on a sample of American and French companies. This can be explained in part by the abundance of information on aggressive earnings management compared with Canada. A summary of some past studies on the relationship between aggressive earnings management and the audit committee is presented in table 1 .

Table 1. Summary of a few past studies on the relationship between aggressive earnings management and the $\mathrm{AC}$

\begin{tabular}{|c|c|c|c|c|c|c|c|c|}
\hline $\begin{array}{l}\mathrm{AC} \\
\text { Characteritics }\end{array}$ & $\begin{array}{l}\text { Bédard } \\
\text { et al. } \\
(2001)\end{array}$ & $\begin{array}{l}\text { Xie et } \\
\text { al. } \\
\text { (2003) }\end{array}$ & $\begin{array}{l}\text { Bédard et al. } \\
\text { (2004) }\end{array}$ & $\begin{array}{l}\text { Gul et } \\
\text { al. } \\
\text { (2007) }\end{array}$ & $\begin{array}{l}\text { Lin et } \\
\text { Hwang } \\
(2009)\end{array}$ & $\begin{array}{l}\text { Ghosh et al. } \\
\text { (2011) }\end{array}$ & $\begin{array}{l}\text { Lan et al. } \\
\text { (2011) }\end{array}$ & $\begin{array}{l}\text { Thomas } \\
\text { (2011) }\end{array}$ \\
\hline $\begin{array}{l}\text { Financial } \\
\text { expertise }\end{array}$ & $(-)$ & & & & $(-)$ & $\begin{array}{l}\text { Not } \\
\text { significant }\end{array}$ & & $(-)$ \\
\hline Diversity & & & & $(-)$ & & & $\begin{array}{l}\text { Not } \\
\text { significant }\end{array}$ & \\
\hline Activisme & $(-)$ & $(-)$ & $\begin{array}{l}\text { Not } \\
\text { significant }\end{array}$ & & $(-)$ & & & $(-)$ \\
\hline
\end{tabular}




\section{Method}

To achieve the objective of this research we used a sample of Canadian companies listed on the Toronto stock exchange, who were signaled (accused) by the AMF to reissue (restate) their financial statements.

To measure and detect the impact of the AC characteristics on earnings management practices, we use the following AC characteristics: financial expertise, activism and diversity. The earnings management practices are measured by the level of discretionary accruals according to the modified Jones model (1995).

\subsection{Main Sample}

The main sample is composed of 5 Canadian companies: Nortel Corporation, CINAR INC, Silvercorp Metals INC, Hollinger INC et Knowledge House INC.

The criteria for selection were the following:

- The companies are signaled (accused) by the AMF to restate their financial statements before 2004 (when regulation 52-110 on ACs was put in place).

- The companies are publicly listed on the Toronto stock exchange.

- The companies belong to different industries and size.

The advantage of using only Canadian listed companies, excluding foreign companies including American listed companies was to avoid the influence of external factors such as different country regulations and different accounting standards.

The period of the data collection covers the 5 years before the regulatory change, 52-110 on ACs, companies that experienced a history of accounting manipulation. This period allows to observe the possible changes in AC characteristics without influence from the regulation. This approach is similar to that used by Koubaou (2010) with a sample of French companies. A summary of the characteristics of the main sample is presented in Table 2.

Table 2. Main sample description

\begin{tabular}{|l|l|l|l|}
\hline NAME OF COMPANY & $\underline{\text { SECTOR }}$ & $\underline{\text { SIZE: (Total assets) }}$ & PERIOD \\
\hline Silvercorp Metals INC & Mining & \$500 million \$CAN & $1999-2003$ \\
\hline Hollinger Inc & $\begin{array}{l}\text { Communication and } \\
\text { Media }\end{array}$ & \$1 billion \$ CAN & $1999-2003$ \\
\hline Cinar Inc & Cinema & \$500 million \$CAN & $1999-2003$ \\
\hline Nortel Corporation & Industrial technology & \$1 milliard \$ CAN & $1999-2003$ \\
\hline Knowledge house inc & Industrial technology & \$25 millions \$ CAN & $1999-2003$ \\
\hline
\end{tabular}




\subsection{Control Sample}

To verify our hypotheses we developed a control sample including 5 companies. We control for size, industry and the date we collected the data. The steps to select our firms were as follows:

- For each company in the main sample, another company with similar size was identified.

- For each company in the main sample, we chose a similar company listed in the Toronto Stock exchange.

- Each company needed to be in the same industry.

Given these selection criteria, here is this list of the companies in the control sample: Polymet Mining corp, Alcatel Canada, Transcontinental INC, Téléfilm Canada et Benvest Capital INC. A summary of the characteristics of the control sample are presented in Table 3.

Table 3. Control sample description

\begin{tabular}{|l|l|l|l|}
\hline NAME OF COMPANY & $\underline{\text { SECTOR }}$ & $\begin{array}{l}\underline{\text { SIZE }} \\
\text { Total Assets }\end{array}$ & $\underline{\text { PERIOD }}$ \\
\hline Polymet Mining corp & Mining sector & \$500 millions CAN & $1999-2003$ \\
\hline $\begin{array}{l}\text { TRANSCONTINENTAL } \\
\text { INC }\end{array}$ & $\begin{array}{l}\text { Communication and } \\
\text { Media }\end{array}$ & \$1 milliard CAN & $1999-2003$ \\
\hline Téléfilm Canada & Cinema production & \$500 millions CAN & $1999-2003$ \\
\hline ALCATEL Canada & Industrial technology & \$1 milliard CAN & $1999-2003$ \\
\hline CORECO & Industrial technology & \$25 millions CAN & $1999-2003$ \\
\hline
\end{tabular}

\subsection{Regression Model}

In addition to our main variables of interest, this model controls for variables that could have a direct relationship with discretionary accruals, earnings management and AC characteristics. These variables are company size, debt policy, shareholder structure and Board independence.

To test the relationship between AC characteristics and earnings management we used the following model:

ACCD $_{i t}=\alpha 0+\alpha_{1}$ EXPERT $_{i t}+\alpha_{2}$ DIVERT $_{i t}+\alpha_{3}$ ACTV $_{i t}+\alpha_{4}\left(\right.$ Board IND $_{i t}+\alpha_{5} E$ DDT $T_{i t}+\alpha_{6}$ OWNER BLOCK $K_{i t}+\alpha_{7} T M B+\varepsilon_{i t}$ 
Where:

$\mathrm{ACCD}_{\mathrm{it}}$ : the level of discretionary accruals;

EXPERT $_{\mathrm{it}}$ : financial expertise of AC members;

DIVERT $_{\text {it }}$ : diversity of AC members measured by a dummy variable;

DIVERT $_{\mathrm{it}}=1$ when there is a women in the comity and 0 when there is not;

$\mathrm{ACTV}_{\mathrm{it}}: \mathrm{AC}$ activism $=$ the number of $\mathrm{AC}$ meetings;

BOARD IND $\mathrm{it}_{\mathrm{it}}$ : Board of Directors independence;

ENDT $_{\text {it: }}$ the level of corporate debt: Debt ratio = total long-term debt / total assets;

OWNER BLOCK $\mathrm{it}_{\mathrm{it}}$ the $\%$ of total shares held by controlling shareholders with more than $10 \%$ of voting rights;

TMB: Ratio market to book: measures the company's growth = market value / book value;

$\alpha_{s}, ß s, \partial_{s}$ : Model coefficients that could be positive or negative according to the results;

$\varepsilon_{\text {it: }}$ error term.

\subsection{Dependent Variable: Aggressive Earnings Management}

The proxy we use for aggressive earnings management practices is discretionary accruals similar to other similar research (Sloan, 1996; Guidry et al., 1998; Nanda et Wysocki, 2003).

Discretionary accruals capture all possible earnings management practices measured by the totality of expenses and revenues accounted for in the income statement (Cormier \& Magnan, 1996).

Based on similar research we borrow a model that helps us estimate the total accruals (Sloan, 1996; Guidry et al., 1998; Leuz, Nanda et Wysocki, 2003):

$$
A C C T_{i t} / A T_{i t-1}=\alpha_{s} / A T_{i t-1}+\beta_{s}\left(I M M O_{i t}\right) / A T_{i t-1}+\delta_{s}\left(V E N T_{i t}\right) / A T_{i t-1}+\varepsilon_{i t}
$$

Where:

$\mathrm{ACCT}_{\mathrm{it}}$ : total accruals I during year $(\mathrm{t})$;

$\mathrm{AT}_{\mathrm{it}-1}$ : total assets during year ( $\left.\mathrm{t}-1\right)$;

$\mathrm{VENT}_{\mathrm{it}}$ : Net sales during the year between year $(\mathrm{t})$ and $(\mathrm{t}-1)$;

$\mathrm{IMMO}_{\mathrm{it}}$ : Fixed assest during year $(\mathrm{t})$;

$\varepsilon_{\mathrm{it}}$ : error term during the year $(\mathrm{t})$;

$\alpha_{\mathrm{s}}, ß \mathrm{~s}, \partial_{\mathrm{s}}$ : model coefficients. 


\section{Macrothink}

Total accruals are comprised of discretionary accruals and non-discretionary accruals

$$
A C C T_{i t}=A C D_{i t}+A C N D_{i t}
$$

Where:

$\mathrm{ACCT}_{\mathrm{it}}$ : total accruals of the firm during year $(\mathrm{t})$;

$\mathrm{ACD}_{\mathrm{it}}$ : discretionary accruals;

$\mathrm{ACND}_{\mathrm{it}}$ : non discretionary accruals.

Discretionary accruals are estimated using the modified Jones model (1994):

$$
A C C D_{i t}=A C C T_{i t} / A T_{i t-1}-\left[\alpha_{s} / A T_{i t-1}+\beta_{s}\left(I M M O_{i t}\right) / A T_{i t-1}+\delta_{s}\left(V E N T_{i t}\right) / A T_{i t-1}\right]
$$

Where:

$\mathrm{ACCD}_{\mathrm{it}}$ : discretinnary accruals of the firm during year $(\mathrm{t})$;

$\mathrm{ACCT}_{\mathrm{it}}$ : total accruals of the firm during year $(\mathrm{t})$;

$\mathrm{AT}_{\mathrm{it}-1}$ : total assets of the firm during year $(\mathrm{t}-1)$;

$\mathrm{VENT}_{\mathrm{it}}$ : Net sales during between the years $(\mathrm{t})$ and $(\mathrm{t}-1)$;

$\mathrm{IMMO}_{\text {it: }}$ Fixed assets during year $(\mathrm{t})$.

By conducting linear regressions by company and by year pour each sample; we calculated the value of non-discretionary accruals for each company for a period of 5 years. The discretionary accruals were finally determined by subtracting the average total accruals and discretionary accruals (determined by linear regressions). This method is similar to an approach by Piot and Janin (2005) with a sample of French companies.

\subsection{Financial Expertise}

According to the national policy 52-110 it is not necessary that AC members have in depth knowledge of accounting standards. This variable (Expert) measures the number of members that have an accounting or financial title. This variable was also used by Bédard et al. (2001); Lin et Hwang (2009); et Thomas (2011); Ghosh et al. (2011).

\subsection{Activism}

The AC needs to meet regularly with management as well as internal and external auditors on all important accounting issues and therefore analyzing the impact of the frequency of meetings on earnings management practices is important (Lin et Hwang, 2009).

The variable (ACTV) measures the total number of AC meetings with members of management and the Board of Directors during a year. It is measured by the number of ordinary and extraordinary meetings (Thomas, 2011; Xie et al., 2003; Lin et Hwang, 2009; et Bedard et al., 2004). 


\subsection{Diversity}

The diversity of an $\mathrm{AC}$ is defined as the variation of characteristics among the members such as the knowledge of the industry, management and financial experience, areas of competency, style of learning, education, origin, age and values (Coffey et Wang, 1998). However, in this research the variable (DIVERT) measures the presence of women on the AC. This variable is also used by Lan et al. (2011) and Gul et al. (2007). The diversity in a AC is measured by the dichotomous variable that has a value of 1 with the presence of women on an $\mathrm{AC}$ and a value of 0 otherwise.

\subsection{Control Variables}

This variable (ENDT) measures the level of debt of the firm. It is measured by the following ratio: total long-term debt / total assets. Dechow et al. (1996) and et Klein (2002) showed a positive relationship between the level of debt and earnings management. This could be explained by the fact that the debt contract constitutes a source document to reduce information asymmetry and to limit opportunistic behavior by management. Also, a company with a high debt level is more susceptible to execute more earnings management (Dechow et al., 1996).

\subsection{Ownership Concentration}

This variable is measured by the total percentage of shares held by shareholders possessing more than $10 \%$ of voting rights. This variable was used by Bozec (2008); Ding et al. (2007); et $\mathrm{Liu}$ et $\mathrm{Lu}$ (2007) who argue that the concentration of ownership decreases earnings management. Also, a study conducted by Rao et Lee-Sing (1995) showed that 55\% of Canadian companies are controlled by dominating shareholders; therefore it is important to control for the concentration of ownership

\subsection{Independence}

This variable (Board IND) is measured by the percentage of independence administrators on the Board of Directors. This variable was used by several researchers to explain discretionary accruals (Abbott et al., 2004; Agrawal et Chadha, 2005; Cornett et al., 2006; Davidson et al., 2005; et Peasnell et al., 2006; Baber et al., 2006; Rahman et al., 2006).

\subsection{Market to Book Ratio}

This variable (TMB) is an indicator of growth for a company. It is measured by the market value / book value ratio. This variable was used to explain discretionary accruals by other researchers such as Skinner et Sloan (2002) et Klein (2002).

\section{Results}

\subsection{Descriptive Statistics}

The descriptive statistics of the 5 companies in the main sample are presented in Table 4 . These statistics show that the average number of AC independence and $40 \%$ are women. The average number of meetings is 5.5 per year. On average $52 \%$ of the AC members are 
financial experts (they have an accounting title). This result corroborates the study conducted by Donelson et al. (2013) who determined an average of 59\%. The level of debt of the companies was on average $19.30 \%$ similar to the study by Shen et Chih (2007) (18.95\%). An average of $57 \%$ of members on the Board of Directors are independent.

Also, the controlling shareholders possess on average $48.1 \%$ of the voting rights, similar to Faccio et al. (2002). Finally the average of discretionary accruals (ACD) is (-.0411), similar to Khothari et al. (2005) which showed (-0.022).

Table 4. Descriptive statistics

\begin{tabular}{|l|l|l|l|l|}
\hline MAIN SAMPLE & MIN & MAX & AVERAGE & $\begin{array}{l}\text { STANDARD } \\
\text { DEVIATION }\end{array}$ \\
\hline DIVERT & 0 & 1 & 0.40 & 0.54772256 \\
\hline ACTV & 10.6 & 4.00 & 5.52 & 2.87262946 \\
\hline EXPERT & 0 & 1.60 & 0.52 & 0.74296702 \\
\hline ENDT & 0.05 & 0.60 & 0.1929 & 0.25657364 \\
\hline BOARD IND & 0.4 & 0.87492 & 0.571037 & 0.19341372 \\
\hline OWNER BLOCK & 0 & 0.6676 & 0.481036 & 0.27720688 \\
\hline MTB & 0.015 & 1.080 & 0.6537333 & 0.56339401 \\
\hline ACD & -0.3333 & 0.2511 & -0.0411 & 0.10524 \\
\hline
\end{tabular}

\subsection{Correlation Analysis}

Table 5 shows a correlation matrix, which highlights a negative relationship between financial expertise and discretionary accruals. However, no correlation is detected between activism, diversity and the level of discretionary accruals. Also, the matrix shows that the level of accruals is negatively related to the structure of ownership.

Table 5. Matrix of correlations

\begin{tabular}{|l|l|l|l|l|l|l|l|}
\hline VARIABLE & DIVERT & ACTV & EXPERT & INDCA & OWBLOK & MTB & ACD \\
\hline DIVERT & 1 & 0.468 & -0.136 & -0.429 & -0.126 & -0.428 & 0.305 \\
\hline ACTV & 0.468 & 1 & $0.774^{*}$ & -0.095 & 0.159 & -0.137 & 0.016 \\
\hline EXPERT & -0.136 & $0.774 *$ & 1 & 0.418 & -0.446 & 0.123 & -0.395 \\
\hline INDCA & -0.429 & -0.095 & 0.418 & 1 & 0.497 & 0.411 & -0.659 \\
\hline OWBLOK & -0.126 & 0.159 & 0.446 & 0.497 & 1 & -0.547 & $-0.968^{* * *}$ \\
\hline MTB & -0.428 & -0.137 & 0.123 & 0.411 & -0.547 & 1 & 0.369 \\
\hline ACD & 0.305 & 0.016 & -0.395 & -0.659 & -0.968 & 0.369 & 1 \\
\hline
\end{tabular}




\subsection{Overall Results}

Our results show an existence of a negative and significant relationship between activism and financial expertise in Canadian company ACs. These results confirm 2 hypotheses $\mathrm{H} 1$ and $\mathrm{H} 2$ that predicts that financial expertise and activism are negatively related to aggressive earnings management. In other words, the more the $\mathrm{AC}$ members are actively meeting and communicating with others, less are the chances that management will aggressively manipulate earnings. In addition, we found that the more the $\mathrm{AC}$ members were financially literate, the less the chances that management would aggressively manipulate earnings. And finally, we did not identify any significant differences between the main sample and the control group.

\section{Discussion}

The objective of this research was to analyze the impact of a group of AC characteristics on aggressive earnings management. The results of our regression analysis show that financial expertise and $\mathrm{AC}$ activism negatively influence aggressive earnings management. However, our results did not detect any significant relationship between diversity and aggressive earnings management. These results partially confirm our hypotheses.

Based on our results we could conclude that regulatory agencies could encourage Canadian companies to assure that their ACs have strong financially literate members and that these members remain active and hold frequent meetings, to assure an effective communication with management.

To the best of our knowledge this research consists of a rare case study that analyses the impact of a group of $\mathrm{AC}$ characteristics such as activism, financial expertise and $\mathrm{AC}$ member diversity on aggressive earnings management practices. Past research has only studied the frequency of meetings and financial expertise (Lin et Hawang, 2009), or diversity (Gul et al., 2007), but never all the characteristics at the same time.

Also, this is one of the first studies that uses Canadian information whereas the majority of the studies relied on American and European data. This could be explained by the very limited amount of aggressive earnings management accusations in Canada. This also justifies somewhat our limited sample size.

We also attempted to contribute theoretically by proposing a conceptual framework that could be used to help explain the different AC characteristics. These definitions come from the AC Canadian National Policy 52-110.

Finally, this research contributes to the existing governance literature regarding the role of the $\mathrm{AC}$ as a mechanism to detect aggressive earnings management, which allows for a better comprehension of the presumed relationship between the governance system of a company and the reliability of financial information.

The results of our study should however be interpreted taking into account certain limits. In regards to external validity, since this study is based on 10 Canadian companies, 5 in the main sample and another 5 in the control group, we cannot generalize the results. 
Furthermore, as with each case study, the identification of a representative sample is difficult to achieve

This study opens up new avenues of research. We investigated AC characteristics for 5 years prior to regulatory changes in 2004 . We encourage future research to analyze these same AC characteristics after the obligatory implication of these regulations and to compare the results with our results. Future research could also investigate other irregularities other than financial statement restatements signaled by the AMF.

\section{Conclusion}

When business managers aggressively manage earnings, investors might not have access to financial information that represents the economic reality of the corporation. This could cause severe distrust and lack of confidence among investors regarding the accuracy of financial information disclosed by public companies. To help build and maintain the investors' level of confidence, public companies are required to have an Audit Committee that oversees the preparation and disclosure of corporate financial information. The results of this research paper show that governance bodies could reduce aggressive earnings management practices by assuring that the members of corporate Audit Committees maintain strong financial competency and also assure that the Audit Committee members meet and communicate frequently. By doing so could increase the investor's confidence in publically disclosed financial information.

\section{References}

Abbott, L. J., Parker, S., \& Peters, G. F. (2006). Earnings management, litigation risk, and asymmetric audit fee responses. Auditing: A Journal of Practice Theory, 25(1), 8598. http://dx.doi.org/10.2308/aud.2006.25.1.85

Barnea, A., Ronen, J., \& Sadan, S. (1975). The Implementation of Accounting objectives: An Application to Extraordinary Items. Accounting Review, 50(1), 58.

Bédard, J., Chtourou, S. M., \& Courteau, L. (2004). The effect of audit committee expertise independence, and activity on aggressive earnings management. Auditing: A Journal of Practice \& Theory, 23(2), 13-35. http://dx.doi.org/10.2308/aud.2004.23.2.13

Berle, A., \& et Means, G. (1932). The modern corporation and private property. New York: Éditions Macmillan Co.

Black, E. L., Sellers, K. F., \& Manly, T. S. (1998). Earnings Management Using Asset Sales: An International Study of Countries Allowing Noncurrent Asset Revaluation. Journal of $\begin{array}{llll}\text { Business Finance } \quad \& \quad \text { Accounting, } & \text { 25(9/10), }\end{array}$ http://dx.doi.org/10.1111/1468-5957.00238

Bozec, Y. (2008). Concentration de l'actionnariat, séparation des droits de vote et des droits de propriété et gestion des bénéfices: Une étude empirique canadienne. Canadian Journal of Administrative Sciences/Revue Canadienne des Sciences de l'Administration, 25(1), 67-82. http://dx.doi.org/10.1002/cjas.53 
Breton, G., \& et Schatt, A. (2003). Manipulation comptable: Les dirigeants et les autres parties prenantes. La revue du financier, 139, 18-25.

Chtourou, S. M., Bedard, J., \& Courteau, L. (2001). Corporate governance and earnings management. University of Laval, Quebec, Canada.

Coffey, B. S., \& Wang, J. (1998). Board diversity and managerial control as predictors of corporate social performance. Journal of Business Ethics, 17(14), 1595-1603. http://dx.doi.org/10.1023/A:1005748230228

Cormier, D., \& Magnan, M. (1995). Le cas des firmes publiant des prévisions lors d'un premier appel public à l'épargne. Comptabilité-Contrôle-Audit, 1, 45-61. http://dx.doi.org/10.3917/cca.011.0045

Cornett, M. M., Marcus, A. J., Saunders, A., \& Tehranian, H. (2007). The impact of institutional ownership on corporate operating performance. Journal of Banking \& Finance, 31(6), 1771-1794. http://dx.doi.org/10.1016/j.jbankfin.2006.08.006

Davidson, R., Goodwin-Stewart, J., \& Kent, P. (2005). Internal governance structures and earnings management. Accounting \& Finance, 45(2), 241-267. http://dx.doi.org/10.1111/j.1467-629x.2004.00132.x

Dechow, P. M., \& Dichev, I. D. (2002). The quality of accruals and earnings: The role of accrual estimation errors. The accounting review, 77(s-1), 35-59. http://dx.doi.org/10.2308/accr.2002.77.s-1.35

Dechow, P., Sloan, R., \& Sweeney, A. (1995). Detecting earnings management. The Accounting Review, 70, 193-225.

DeFond, M. L., \& Jiambalvo, J. (1994). Debt covenant violation and abnormal accruals. Journal of Accounting and Economics, 117, 145-176. http://dx.doi.org/10.1016/0165-4101(94)90008-6

Ding, Y., Hope, O. K., Jeanjean, T., \& Stolowy, H. (2007). Differences between domestic accounting standards and IAS: Measurement, determinants and implications. Journal of $\begin{array}{lllll}\text { Accounting } \quad \text { and Public } & \text { Policy, } & \text { 26(1), }\end{array}$ http://dx.doi.org/10.1016/j.jaccpubpol.2006.11.001

Donelson, D., McInnis, J., \& Mergenthaler, R. (2013). Discontinuities and earnings management: Evidence from restatements related to securities litigation. Contemporary Accounting Research, 30(1), 242-268. http://dx.doi.org/10.1111/j.1911-3846.2012.01150.x

Erickson, M., \& Wang, S. W. (1999). Earnings management by acquiring firms in stock for stock mergers. Journal of Accounting and Economics, 27(2), 149-176. http://dx.doi.org/10.1016/S0165-4101(99)00008-7

Francis, J., LaFond, R., Olsson, P., \& Schipper, K. (2005). The market pricing of accruals quality. Journal of Accounting and Economics, 39(2), 295-327. http://dx.doi.org/10.1016/j.jacceco.2004.06.003 
Ghosh, A., Marra, A., \& Moon, D. (2010). Corporate Boards, Audit Committees, and Earnings Management: Pre- and Post-SOX Evidence. Journal of Business Finance \& Accounting, 37. http://dx.doi.org/10.1111/j.1468-5957.2010.02218.x

Godard, L., \& et Schatt, A. (2004). Caractéristiques et fonctionnement des conseils d'administration français. Cahier du FARGO, N¹040201, Février, pp. 1-27.

Guidry, F., Leone, A., \& Rock, S. (1999).Earnings-based bonus plans and earnings management business unit managers. Journal of Accounting and Economics, 26, 113-142. http://dx.doi.org/10.1016/S0165-4101(98)00037-8

Gul, F. A., Jaggi, B. L., \& Krishnan, G. V. (2007). Auditor independence: evidence on the joint effects of auditor tenure and nonaudit fees. Auditing: A Journal of Practice \& Theory, 26(2), 117-142. http://dx.doi.org/10.2308/aud.2007.26.2.117

Jensen, M. C. (1993). The Modern Industrial Revolution, Exit and the Failure of Internal Control Systems. Journal of Finance, 48(3), 831-880. http://dx.doi.org/10.1111/j.1540-6261.1993.tb04022.x

Klein, A. (2002). Audit Committee, Board of Directors and Earnings Management. Journal of Accounting and Economics, 33, 375-400. http://dx.doi.org/10.1016/S0165-4101(02)00059-9

Kothari, S. P., Leone, A. J., \& Wasley, C. E. (2005). Performance matched discretionary accrual measures. Journal of Accounting and Economics, 39(1), 163-197. http://dx.doi.org/10.1016/j.jacceco.2004.11.002

Koubaa, B. A. (2010). Corporate governance and earnings management: evidence from French. 22 Asian-Pacific Conference on International Accounting Issues, Gold Coast, Australie.

Lan et al. (2011). Does Female Directorship on Independent Audit Committees Constrain Earnings Management? Journal of Business Ethics, 99(3), 369-382. http://dx.doi.org/10.1007/s10551-010-0657-0

Lang, M., Smith Raedy, J., \& Wilson, W. (2006). Earnings management and cross listing: Are reconciled earnings comparable to US earnings? Journal of Accounting and Economics, 42(1), 255-283. http://dx.doi.org/10.1016/j.jacceco.2006.04.005

Lin, J. W., \& Hwang, M. I. (2010). Audit Quality, Corporate Governance, and Earnings Management: A Meta-Analysis. International Journal of Auditing, 14, 57-77. http://dx.doi.org/10.1111/j.1099-1123.2009.00403.x

Liu, Q., \& Lu, Z. J. (2007). Corporate governance and earnings management in the Chinese listed companies: A tunneling perspective. Journal of Corporate Finance, 13(5), 881-906. http://dx.doi.org/10.1016/j.jcorpfin.2007.07.003

Matoussi, H., \& et Mahfoudh, I. (2006). Composition du conseil d'administration et gestion opportuniste des resultants. Working Paper, Congès de l'Association Francophone de 
comptabilité, pp. 1-22.

Menard. (2011). Dictionnaire de la comptabilité et de la gestion financière. Publié par l'Institut canadien des comptables agréés en 2011. Disponible à la bibliothèque de l'université de Québec à Montréal.

Naciri, A. (2010). Internal and externat aspects of corporate governance. Éditions: Rout Jedge, New York.

Peasnell, K. V., Pope, P. F., \& Young, S. (1998). Outside directors, board effectiveness, and earnings management. University of Lancaster.

Piot, C., \& et Janin, R. (2005). Qualité de l'audit, gouvernance et gestion du résultat comptable en France. les enjeux, Juin, Montréal Canada, p. 1.

Pochet. (1998). Inefficacité des mécanismes de contrôle managérial: le rôle de l'information comptable dans le gouvernement de l'entreprise. Comptabilité, contrôle et audit, Tome 4 Volume 2 - Septembre 1998. http://dx.doi.org/10.3917/cca.042.0071

Rahman, R. A., \& et Ali, F. H. M. (2006). Board, audit committee, culture and earnings management: Malaysian evidence. Managerial Auditing Journal, 21(7), 783-804. http://dx.doi.org/10.1108/02686900610680549

Ronen, J., \& Sadan, S. (1975). Classificatory Smoothing: Alternative Income Models. Journal of Accounting Research, 13(1), 133-149. http://dx.doi.org/10.2307/2490652

Shen, Ch. H., \& Chih, H. L. (2005). Investor Protection, Prospect Theory, and Earnings Management: An International Comparison of the Banking Industry. Journal of Banking and Finance, 29, 2675-2697. http://dx.doi.org/10.1016/j.jbankfin.2004.10.004

Stolowy, H. (1999). Comptabilité créative. In Encyclopédie de Comptabilité, Contrôle de Gestion et Audit: Economica, 157-178.

Stolowy, H., \& Breton, G. (2003). La gestion des données comptables: une revue de la littérature. Comptabilité-Contrôle-Audit, 9, 125-151. http://dx.doi.org/10.3917/cca.091.0125

Thomas. (2011). La qualité du comité d'audit et la gestion des résultats en France. Toulouse Business School, 1-36.

Wang, J. (1998). Board diversity and managerial control as predictors of corporate social performance. Journal of Business Ethics, 17(14), 1595-1603. http://dx.doi.org/10.1023/A:1005748230228

Warfield, T. D., Wild, J. J., \& Wild, K. L. (1995). Managerial ownership, accounting choices, and informativeness of earnings. Journal of Accounting and Economics, 20(1), 61-91. http://dx.doi.org/10.1016/0165-4101(94)00393-J

Xie, B., Davidson, W. N., \& DaDalt, P. (2003). Earnings management and corporate governance: the role of the board and the audit committee. Journal of Corporate Finance, 9, 295-316. http://dx.doi.org/10.1016/S0929-1199(02)00006-8 


\section{Copyright Disclaimer}

Copyright for this article is retained by the author(s), with first publication rights granted to the journal.

This is an open-access article distributed under the terms and conditions of the Creative Commons Attribution license (http://creativecommons.org/licenses/by/3.0/). 